\title{
Comparison of analytical methods in testing soil fertility
}

\author{
RAINA NISKANEN and ANTTI JAAKKOLA \\ University of Helsinki, Department of Agricultural Chemistry, \\ SF-00710 HELSINKI, Finland
}

\begin{abstract}
Analytical methods for testing soil fertility were compared in a material of 430 topsoil samples. The samples were analyzed for particle-size distribution, organic carbon content, $\mathrm{pH}\left(\mathrm{CaCl}_{2}\right)$, exchangeable $\mathrm{Ca}$ and $\mathrm{Mg}$ extracted with $1 \mathrm{M}$ ammonium acetate $(\mathrm{pH} 7)$ and $1 \mathrm{M} \mathrm{KCl}$, exchangeable $\mathrm{K}$ extracted with $1 \mathrm{M}$ ammonium acetate $(\mathrm{pH} 7)$ and $\mathrm{P}$ extracted by the Bray 1 method. These soil properties were compared with the soil textural class and humus content class estimated visually, $\mathrm{pH}\left(\mathrm{H}_{2} \mathrm{O}\right)$ and $\mathrm{Ca}, \mathrm{Mg}, \mathrm{K}$ and $\mathrm{P}$ extracted with acid ammonium acetate.

The estimation of soil textural class was quite successful, but the content of organic matter was frequently underestimated. $\mathrm{pH}\left(\mathrm{H}_{2} \mathrm{O}\right)$ and $\mathrm{pH}\left(\mathrm{CaCl}_{2}\right)$ were highly correlated and $95 \%$ of the variation in $\mathrm{pH}\left(\mathrm{H}_{2} \mathrm{O}\right)$ was explained by $\mathrm{pH}\left(\mathrm{CaCl}_{2}\right)$. Exchangeable $\mathrm{Ca}$ together with $\mathrm{pH}\left(\mathrm{CaCl}_{2}\right)$ explained about $90 \%$ of the variation in $\mathrm{Ca}$ extracted with acid ammonium acetate. Exchangeable $\mathrm{Mg}$ explained about $70 \%$ of the variation in $\mathrm{Mg}$ extracted with acid ammonium acetate. Exchangeable $\mathrm{K}$ explained $90 \%$ of the variation in $\mathrm{K}$ extracted with acid ammonium acetate. The Bray $1 \mathrm{P}$ and $\mathrm{pH}\left(\mathrm{CaCl}_{2}\right)$ explained $60 \%$ of the variation in $\mathrm{P}$ extracted with acid ammonium acetate. $\mathrm{pH}\left(\mathrm{CaCl}_{2}\right)$, clay and organic carbon content explained $72-83 \%$ of the variation in $\mathrm{Ca}$. $\mathrm{Mg}, \mathrm{K}$ and $\mathrm{P}$ were not highly dependent on $\mathrm{pH}$, particle-size distribution and organic carbon content of soil.
\end{abstract}

\section{Introduction}

For the estimation of soil fertility status, various methods have been developed. In Finland, acid ammonium acetate extraction (VUORINEN and MÄKITIE 1955) is extensively used in testing the soil nutrient status. In soil testing, soil textural class and humus content are estimated visually and soil $\mathrm{pH}$ is measured in water suspension. The purpose of this study was to compare the results of the adopted soil testing analysis with other soil test values. The reference methods were chosen among those widely used in other countries.

\section{Material and methods}

The research material consisted of 430 plough layer $(0-25 \mathrm{~cm})$ samples collected for mapping down soil characteristics at the agricultural area of the Viikki Experimental Farm. The characteristics of the soil samples have previously been described by JOKINEN (1983 and 1984). 
The samples were air-dried and ground to pass a 2-mm sieve. The particle-size distribution of the inorganic matter in the soil samples was determined by the pipette method (ELoNEN 1971). The $\mathrm{pH}$ of the soil was measured in a stirred soil- $0.01 \mathrm{M} \mathrm{CaCl}$ suspension (1: 2.5) (RYTI 1965). The organic carbon content of the soil samples was determined using a modified (Graham 1948) Alten's wet combustion method. Exchangeable $\mathrm{Ca}$ and $\mathrm{Mg}$ were extracted from $10 \mathrm{~g}$ soil by four successive treatments with $50 \mathrm{ml}$ of $1 \mathrm{M}$ ammonium acetate $(\mathrm{pH} 7.0)$ as.. with $50 \mathrm{ml}$ of $1 \mathrm{M} \mathrm{KCl}$ and determined by atomic absorption spectrophotometry. Exchangeable $\mathrm{K}$ was extracted with $1 \mathrm{M}$ ammonium acetate ( $\mathrm{pH} 7.0)$ and determined by flame photometry. Phosphorus was extracted with Bray 1 extractant (0.03 M NaF, $0.025 \mathrm{M} \mathrm{HCl}$ ) (Bray and KURTZ 1945), the extraction ratio being $1: 10$ w/v (KaILA 1965) and determined by a molybdenum blue method (KaILA 1955). The pH of the soil- $\mathrm{H}_{2} \mathrm{O}$ suspension ( $\left.1: 2.5\right)$, and $\mathrm{Ca}$, $\mathrm{Mg}, \mathrm{K}$ and $\mathrm{P}$ extractable with acid ammonium acetate $(0.5 \mathrm{M}$ acetic acid, $0.5 \mathrm{M}$ ammonium acetate, $\mathrm{pH} 4.65$, ratio $1: 10 \mathrm{v} / \mathrm{v}$ ) (VUORINEN and MÄKITIE 1955) were determined at a commercial soil testing laboratory (Viljavuuspalvelu $\mathrm{Oy}$ ). The textural class and the humus content of the soils were estimated visually at the same laboratory.

The particle sizes of soils were classified as follows:

$\begin{array}{ll}\text { Particle-size fraction } & \text { Diameter, mm } \\ \text { Clay } & <0.002 \\ \text { Silt } & 0.002-0.02 \\ \text { Finer finesand } & 0.02-0.06 \\ \text { Coarser finesand } & 0.06-0.2 \\ \text { Sand } & 0.2-2\end{array}$

The textural classes aimed at were as follows:

Textural class

\begin{tabular}{ccc}
\multicolumn{3}{c}{$\begin{array}{c}\text { Proportion of particle-size } \\
\text { fractions, } \%\end{array}$} \\
Clay & Silt & $\begin{array}{c}\text { Coarser } \\
\text { fractions }\end{array}$
\end{tabular}

$\begin{array}{llll}\text { Heavy clay } & >60 & & \\ \text { Silty clay } & 30-60 & & <20 \\ \text { Sandy clay } & 30-60 & & >20 \\ \text { Silt } & <30 & >50 & \\ \text { Loam } & <30 & <50 & <50 \\ \text { Coarser soils } & <30 & & >50\end{array}$

Coarser soils are classified according to the dominating coarser fraction. Gyttja clay is a soil with a clay content over $30 \%$ and with a $3-6 \%$ organic matter content in the subsoil. Soils with a clay content under $30 \%$ may be defined as clayey if the clay content is considerable. Coarser soils with a considerable silt content may be defined as silty and silt soils with considerable content of coarser fractions as sandy.

The soils were classified according to the content of organic matter as follows:

$\begin{array}{lll}\begin{array}{l}\text { Content of } \\ \text { organic matter } \\ \text { in the soil, \% }\end{array} & \begin{array}{l}\text { Corresponding } \\ \text { content of organic } \\ \text { carbon, \% }\end{array} & \begin{array}{l}\text { Humus } \\ \text { content } \\ \text { class }\end{array} \\ <3 & <1.7 & \text { low } \\ 3-6 & 1.7-3.5 & \text { medium } \\ 6-12 & 3.5-7.0 & \text { rich } \\ 12-20 & 7.0-11.6 & \text { very rich } \\ 20-40 & 11.6-23.3 & \text { mould }\end{array}$

The content of organic matter is obtained by multiplying the organic carbon content $(\%)$ with the coefficient 1.72 .

\section{Results}

Soil textural class (visual estimation) and particle-size distribution. Particle-size distribution is presented in Table 1. The particlesize distribution varied greatly in different fields. However, the proportion of sand fractions was low in the whole area and finesand fractions averaged 20 and $28 \%$ of the particle-size distribution. The mean clay and silt contents were 31 and $17 \%$ of the inorganic material.

The greatest group consisted of 169 coarser finesand samples (Table 2). In this group the mean content of coarser finesand fraction was $47 \%$ of the inorganic material, the contents ranging from $28 \%$ to $81 \%$. The group of finer finesand samples included only 15 samples in which the content of finer finesand fraction averaged $25 \%$. In addition, 12 samples were identified as finesand soils without a more accurate classification. In these samples the proportions of finer and coarser 


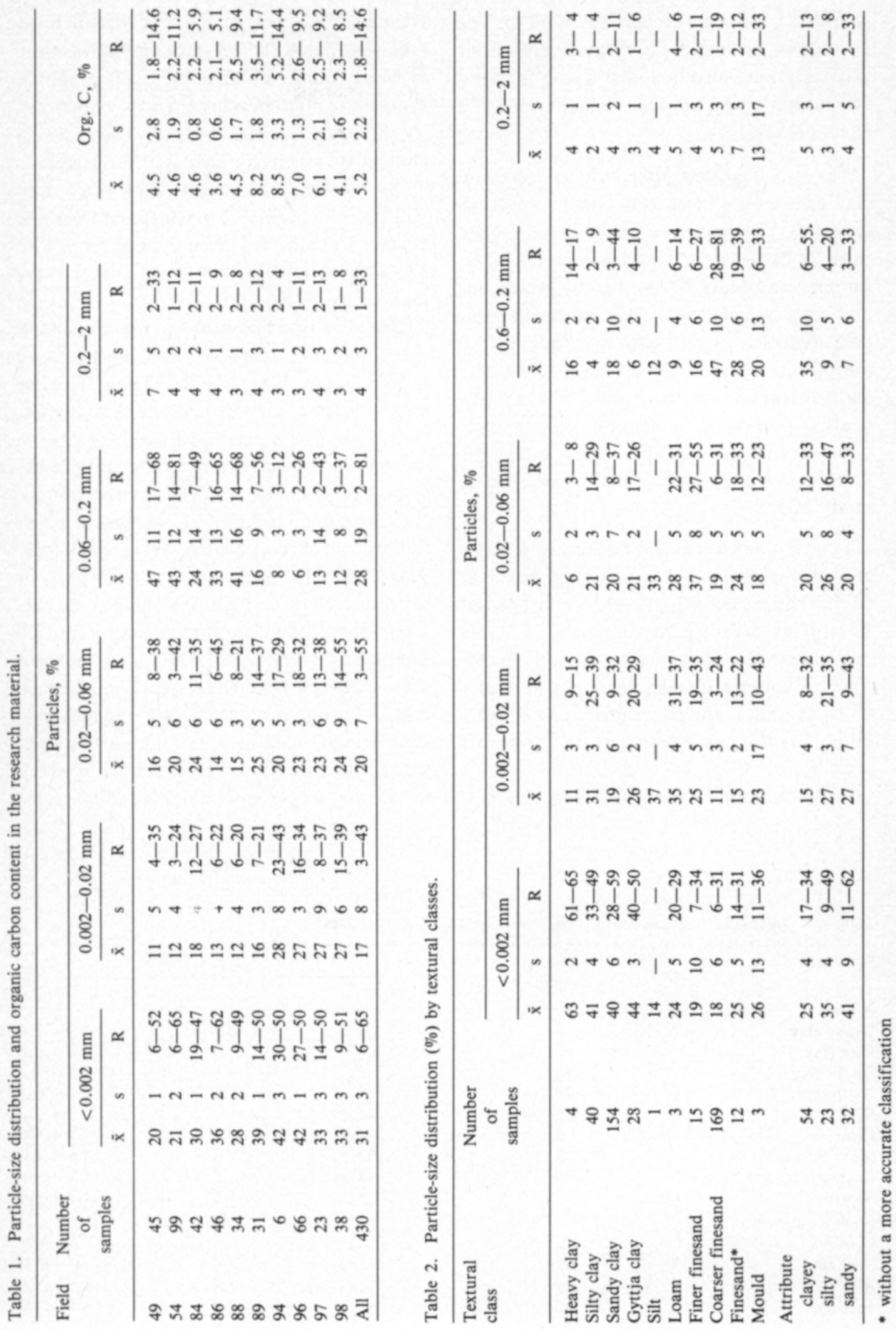


finesand fractions were almost equal (on the average $24 \%$ and $28 \%$, respectively). Four clay soils were also included in the finesand soil groups in which the clay content was $34 \%$ at its highest.

The second greatest group included 154 sandy clay soils with a mean clay content of $40 \%$ (Table 2). The content of clay fraction ranged from $28 \%$ to $59 \%$. The clay content of two samples was under $30 \%$, thereby these samples were not clay soils. The group of samples identified as silty clay soils included 40 samples in which the mean contents of clay and silt fractions were 41 and $31 \%$, respectively. However, the content of coarser fractions was over $20 \%$ in all samples, and all the samples in this group should be classified as sandy clays.

Four samples were identified as heavy clays, and their content of clay fraction was over $60 \%$. The group of gyttja clays consisted of 28 samples, average clay content $44 \%$. Only one sample was identified as silt soil. In this soil the content of silt fraction was under $50 \%$ as well as the content of coarser fractions. So, this soil belongs to the group of loam soils.

Fifty-four samples the clay content of which averaged $25 \%$, range $17-34 \%$, were defined as clayey (Table 2). The clay content was over $30 \%$ in four samples of this group. These samples should be classified as clay soils. Twenty-three samples (excl. silty clays) the silt content of which averaged $27 \%$, range $21-$ $35 \%$, were defined as silty. Thirty-two samples (excl. sandy clays) in which the finer and coarser finesand fractions ranged from 8 to $33 \%$ and from 3 to $33 \%$, respectively, were defined as sandy.

Organic carbon content and humus content class. Organic carbon content averaged $5.2 \%$, range $1.8-14.6 \%$ (Table 1 ). The mean organic carbon content was highest $(7.0 \%)$ in gyttja clays and was high also in the silty and sandy clays $(6.6 \%$ and $5.4 \%$, respectively) (Table 3 ). The humus content class "medium» included 327 samples in which the organic carbon content averaged $4.4 \%$, range $1.9-11.2 \%$ (Table 3 ). On the basis of organic carbon content 186 samples of this group should be classified as wrich" and 25 samples as "very rich". The humus content class "rich" included 88 samples of an average organic carbon content of $7.4 \%$, range $2.5-$ $13.2 \%$. On the basis of organic carbon content 57 samples should be classified as wvery rich", one sample as mould soil and one sam-

Table 3. Organic carbon content in textural and humus content classes.

\begin{tabular}{|c|c|c|c|c|}
\hline \multirow[t]{2}{*}{ Soil class } & \multirow{2}{*}{$\begin{array}{c}\text { Number of } \\
\text { samples }\end{array}$} & \multicolumn{3}{|c|}{ Org. C, \% } \\
\hline & & $\tilde{\mathrm{x}}$ & s & $\mathbf{R}$ \\
\hline Heavy clay & 4 & 3.5 & 0.5 & $2.8-3.8$ \\
\hline Silty clay & 40 & 6.6 & 1.6 & $2.8-9.2$ \\
\hline Sandy clay & 154 & 5.4 & 2.1 & $2.5-11.2$ \\
\hline Gyttja clay & 28 & 7.0 & 1.5 & $4.1-9.5$ \\
\hline Silt & 1 & 2.4 & - & - \\
\hline Loam & 3 & 3.4 & 0.2 & $3.2-3.6$ \\
\hline Finer finesand & 15 & 3.7 & 1.8 & $1.8-7.0$ \\
\hline Coarser finesand & 169 & 4.4 & 1.8 & $1.9-14.2$ \\
\hline Mould & 3 & 13.6 & 1.6 & $11.7-14.6$ \\
\hline \multicolumn{5}{|l|}{ Humus content: } \\
\hline Low & 1 & 1.8 & - & - \\
\hline Medium & 327 & 4.4 & 1.6 & $1.9-11.2$ \\
\hline Rich & 88 & 7.4 & 1.8 & $2.5-13.2$ \\
\hline Very rich & 10 & 9.2 & 2.0 & $6.9-14.2$ \\
\hline
\end{tabular}


ple as "medium». The humus content was considered very rich in 10 samples, one of them should be included in mould soils. Three samples were classified as mould soils.

Soil $\mathrm{pH}$. The $\mathrm{pH}$ measured in water suspension ranged from 4.2 to 7.1 , mean 5.8 (Table 4). The mean $\mathrm{pH}$ measured in $0.01 \mathrm{M} \mathrm{CaCl}_{2}$ suspension was 5.3 , range $4.0-6.8$. The $\mathrm{pH}$ values measured in water and $0.01 \mathrm{M} \mathrm{CaCl}_{2}$ suspensions were highly correlated $(\mathrm{r}=$ $\left.0.98^{* * *}\right)$. The regression equation $\mathrm{pH}\left(\mathrm{H}_{2} \mathrm{O}\right)$ $=0.94+0.91 \mathrm{pH}\left(\mathrm{CaCl}_{2}\right)$ explained $95 \%$ of the variation in $\mathrm{pH}\left(\mathrm{H}_{2} \mathrm{O}\right)$.

The applicability of the regression equation in predicting the mean $\mathrm{pH}\left(\mathrm{H}_{2} \mathrm{O}\right)$ values in different fields was tested so that $\mathrm{pH}\left(\mathrm{H}_{2} \mathrm{O}\right)$ values were calculated using the mean $\mathrm{pH}\left(\mathrm{CaCl}_{2}\right)$ values in different fields. The predicted $\mathrm{pH}\left(\mathrm{H}_{2} \mathrm{O}\right)$ was equal to the mean $\mathrm{pH}\left(\mathrm{H}_{2} \mathrm{O}\right)$ in the fields 54,84 and 89 . In the fields 49, 94, 96 and 98 the predicted value was $0,1 \mathrm{pH}$ unit higher, in the fields 88 and 970.1 and in the field $860.2 \mathrm{pH}$ units lower than the mean $\mathrm{pH}\left(\mathrm{H}_{2} \mathrm{O}\right)$.

The $\mathrm{pH}$ measured in water or $0.01 \mathrm{M}$ $\mathrm{CaCl}_{2}$ suspensions was not highly related to particle-size distribution or organic carbon content of soil. The organic carbon content explained $42 \%$ of the variation in $\mathrm{pH}\left(\mathrm{H}_{2} \mathrm{O}\right)$ and $32 \%$ of the variation in $\mathrm{pH}\left(\mathrm{CaCl}_{2}\right)$. When the effect of silt fraction was also con- sidered, $46 \%$ and $36 \%$ of the variation in $\mathrm{pH}\left(\mathrm{H}_{2} \mathrm{O}\right)$ and $\mathrm{pH}\left(\mathrm{CaCl}_{2}\right)$, respectively, was explained.

Exchangeable calcium. The mean content of calcium extracted with acid ammonium acetate was $1779 \mathrm{mg} / 1$, range $275-3850 \mathrm{mg} / 1$ soil (Table 5). The contents of calcium extracted with $1 \mathrm{M}$ ammonium acetate $(\mathrm{pH} 7)$ and $1 \mathrm{M} \mathrm{KCl}$ averaged 2374 and $2174 \mathrm{mg} / \mathrm{kg}$ soil, respectively. Calcium extracted with $1 \mathrm{M}$ ammonium acetate ( $\mathrm{pH} 7)$ explained $68.7 \%$ of the variation in acid ammonium acetateextractable calcium, the regression equation being $\mathrm{Ca}=348+0.60 \mathrm{Ca}$ (Acet.pH 7). Calcium extracted with $1 \mathrm{M} \mathrm{KCl}$ explained $55.8 \%$ of the variation in acid ammonium acetate-extractable calcium, and the regression equation was $\mathrm{Ca}=507+0.59 \mathrm{Ca}(\mathrm{KCl})$.

The $\mathrm{pH}\left(\mathrm{CaCl}_{2}\right)$ and neutral ammonium acetate- or potassium chloride-extractable calcium together explained most of the variation in acid ammonium acetate-extractable calcium. Acid ammonium acetate-extractable calcium was dependent on $\mathrm{pH}\left(\mathrm{CaCl}_{2}\right)$ and calcium extracted with $1 \mathrm{M}$ ammonium acetate $(\mathrm{pH} 7)$ according to the equation $\mathrm{Ca}=-2039+$ $506 \mathrm{pH}+0.47 \mathrm{Ca}$ (Acet.pH 7). The coefficient of determination was $91.2 \%$. In different fields the values of acid ammonium acetateextractable calcium calculated on the basis of the mean $\mathrm{pH}\left(\mathrm{CaCl}_{2}\right)$ and calcium extracted

Table 4. $\mathrm{pH}$ values measured in water and $0.01 \mathrm{M} \mathrm{CaCl}_{2}$ suspensions.

\begin{tabular}{|c|c|c|c|c|c|c|c|}
\hline \multirow[t]{2}{*}{ Field } & \multirow{2}{*}{$\begin{array}{c}\text { Number of } \\
\text { samples }\end{array}$} & \multicolumn{3}{|c|}{$\mathrm{pH}\left(\mathrm{H}_{2} \mathrm{O}\right)$} & \multicolumn{3}{|c|}{$\mathrm{pH}\left(\mathrm{CaCl}_{2}\right)$} \\
\hline & & $\overline{\mathrm{x}}$ & $s$ & $\mathbf{R}$ & $\overline{\mathbf{x}}$ & s & $\mathbf{R}$ \\
\hline 49 & 45 & 6.3 & 0.5 & $4.8-7.1$ & 6.0 & 0.6 & $4.6-6.8$ \\
\hline 54 & 99 & 6.0 & 0.5 & $4.8-7.0$ & 5.6 & 0.5 & $4.5-6.6$ \\
\hline 84 & 42 & 5.8 & 0.3 & $5.3-6.9$ & 5.3 & 0.4 & $4.8-6.6$ \\
\hline 86 & 46 & 6.2 & 0.2 & $5.7-6.6$ & 5.6 & 0.3 & $4.9-6.1$ \\
\hline 88 & 34 & 5.5 & 0.4 & $4.8-6.2$ & 4.9 & 0.4 & $4.2-5.6$ \\
\hline 89 & 31 & 5.5 & 0.3 & $5.1-6.1$ & 5.0 & 0.3 & $4.5-5.6$ \\
\hline 94 & 6 & 5.2 & 0.5 & $4.2-5.5$ & 4.8 & 0.4 & $4.0-5.1$ \\
\hline 96 & 66 & 5.5 & 0.4 & $4.9-6.9$ & 5.1 & 0.6 & $4.4-6.5$ \\
\hline 97 & 23 & 5.2 & 0.3 & $4.7-5.7$ & 4.6 & 0.3 & $4.2-5.2$ \\
\hline 98 & 38 & 5.7 & 0.5 & $4.9-6.9$ & 5.3 & 0.5 & $4.3-6.6$ \\
\hline All & 430 & 5.8 & 0.5 & $4.2-7.1$ & 5.3 & 0.6 & $4.0-6.8$ \\
\hline
\end{tabular}


with $1 \mathrm{M}$ ammonium acetate ( $\mathrm{pH} 7$ ) according to the regression equation deviated from the mean values as follows:

Field Deviation, \% (No. of samples)

$\begin{array}{lr}49(45) & +5.0 \\ 54(99) & +0.9 \\ 84(42) & -3.9 \\ 86(46) & -9.3 \\ 88(34) & 0.0\end{array}$

Field Deviation, \% (No. of samples)

89(31) $\quad-0.6$

$94(6)+2.2$

96(66) +1.9

$97(23)+4.5$

$98(38)+4.2$

Calcium extracted with $1 \mathrm{M} \mathrm{KCl}$ and $\mathrm{pH}\left(\mathrm{CaCl}_{2}\right)$ together explained $89.9 \%$ of the variation in calcium extracted with acid ammonium acetate, the regression equation being $\mathrm{Ca}=-2442+597 \mathrm{pH}+0.48 \mathrm{Ca}(\mathrm{KCl})$. In different fields the values of acid ammonium acetate-extractable calcium calculated by means of the regression equation deviated from the mean values as follows:

Field Deviation, \% (No. of samples) 49(45) +4. $54(99)+1.1$

84(42) -3.3

$86(46) \quad-6.0$

$88(34)+0.8$
Field Deviation, \% (No. of samples) 89(31) $\quad-0.2$ $94(6)+2.3$ $96(66)+2.8$ 97(23) $\quad-0.2$ $98(38)+6.6$
The dependence of the exchangeable calcium on soil properties was studied using clay and silt content $(\%)$, organic carbon content $(\%)$ and $\mathrm{pH}\left(\mathrm{CaCl}_{2}\right)$ as independent variables in the regression analysis. The $\mathrm{pH}\left(\mathrm{CaCl}_{2}\right)$ of soil alone explained $54 \%$ of the variation in calcium extracted with acid ammonium acetate. Adding the clay content to the variables increased the coefficient of determination to $74 \%$. Adding the organic carbon content to variables increased the coefficient of determination to $82.5 \%$, the regression equation being $\mathrm{Ca}=-4744+16.8$ clay- $\%+1037 \mathrm{pH}+$ 93org.C-\%. Including silt content to the variables increased the coefficient of determination only to $84 \%$.

Calcium extracted with $1 \mathrm{M}$ ammonium acetate ( $\mathrm{pH} 7)$ was not highly correlated with $\mathrm{pH}$, clay nor organic carbon content alone, but $\mathrm{pH}\left(\mathrm{CaCl}_{2}\right)$ and organic carbon content together explained $63 \%$ of the variation in calcium. Addition of clay content to the variables increased the coefficient of determination to $75 \%$, the regression equation being $\mathrm{Ca}$ (Acet.pH 7) $=-6104+22.8$ clay- $\%+$ $1205 \mathrm{pH}+261$ org. C- $\%$. The silt content was an insignificant explainer.

The organic carbon content and $\mathrm{pH}\left(\mathrm{CaCl}_{2}\right)$ of soil explained $55 \%$ of the variation in

Table 5. Exchangeable calcium extracted by acid ammonium acetate, $1 \mathrm{M}$ ammonium acetate $(\mathrm{pH} 7)$ and $1 \mathrm{M} \mathrm{KCl}$ in the research material.

\begin{tabular}{|c|c|c|c|c|c|c|c|c|c|c|}
\hline \multirow[t]{2}{*}{ Field } & \multirow{2}{*}{$\begin{array}{c}\text { Number } \\
\text { of } \\
\text { samples }\end{array}$} & \multicolumn{3}{|c|}{$\begin{array}{c}\text { Acid } \mathrm{NH}_{4} \mathrm{OAc} \text { extractable } \\
\mathrm{Ca} \mathrm{mg/l} \text { soil }\end{array}$} & \multicolumn{3}{|c|}{$\begin{array}{c}1 \mathrm{M} \mathrm{NH}_{4} \mathrm{OAc} \text { extractable } \\
\mathrm{Ca} \mathrm{mg} / \mathrm{kg} \text { soil }\end{array}$} & \multicolumn{3}{|c|}{$\begin{array}{c}1 \mathrm{M} \mathrm{KCl} \text { extractable } \\
\mathrm{Ca} \mathrm{mg} / \mathrm{kg} \text { soil }\end{array}$} \\
\hline & & $\tilde{\mathbf{x}}$ & s & $\mathbf{R}$ & $\tilde{\mathbf{x}}$ & s & $\mathbf{R}$ & $\tilde{\mathrm{x}}$ & s & $\mathbf{R}$ \\
\hline 49 & 45 & 2177 & 595 & $1250-3700$ & 2757 & 862 & $1275-5845$ & 2344 & 696 & $1130-5132$ \\
\hline 54 & 99 & 1830 & 465 & $1025-3850$ & 2238 & 556 & $1035-4325$ & 1975 & 476 & $836-3542$ \\
\hline 84 & 42 & 1742 & 367 & $1075-3100$ & 2195 & 439 & $1495-3930$ & 2005 & 343 & $1364-2970$ \\
\hline 86 & 46 & 2074 & 550 & $700-3000$ & 2312 & 658 & $750-3550$ & 2186 & 604 & $690-3290$ \\
\hline 88 & 34 & 1197 & 277 & $725-2100$ & 1610 & 337 & $1000-2700$ & 1507 & 352 & $826-2502$ \\
\hline 89 & 31 & 1799 & 347 & $1400-3225$ & 2760 & 439 & $1775-3730$ & 2608 & 504 & $780-3444$ \\
\hline 94 & 6 & 1617 & 688 & $275-2100$ & 2688 & 1139 & $502-3537$ & 2564 & 1066 & $546-3394$ \\
\hline 96 & 66 & 2006 & 569 & $1000-3700$ & 3198 & 779 & $1136-5603$ & 3042 & 690 & $1060-4732$ \\
\hline 97 & 23 & 991 & 288 & $600-1900$ & 1593 & 285 & $1215-2269$ & 1426 & 416 & $0-2178$ \\
\hline 98 & 38 & 1493 & 327 & $900-2200$ & 1941 & 437 & $950-3190$ & 1810 & 421 & $368-2798$ \\
\hline All & 430 & 1779 & 560 & $275-3850$ & 2374 & 773 & $502-5845$ & 2174 & 716 & $0-5132$ \\
\hline
\end{tabular}


calcium extracted with $1 \mathrm{M} \mathrm{KCl}$. Addition of clay content to the variables increased the coefficient of determination to $72 \%$. With these variables the regression equation was $\mathrm{Ca}(\mathrm{KCl})=-4888+24.8$ clay- $\%+953 \mathrm{pH}+$ 235org.C-\%.

Exchangeable magnesium. The content of magnesium extracted with acid ammonium acetate averaged $163 \mathrm{mg} / \mathrm{l}$ soil, range $25-$ $1850 \mathrm{mg} / 1$ soil (Table 6). The mean contents of magnesium extracted with $1 \mathrm{M}$ ammonium acetate (pH 7) and $1 \mathrm{M} \mathrm{KCl}$ were 187 and 167 $\mathrm{mg} / \mathrm{kg}$ soil, respectively. Magnesium extracted with $1 \mathrm{M}$ ammonium acetate $(\mathrm{pH} 7)$ explained $72.4 \%$ of the variation in magnesium extracted with acid ammonium acetate, the regression equation being $\mathrm{Mg}=-23.6+$ $1.0 \mathrm{Mg}$ (Acet.pH 7). Considering the effect of $\mathrm{pH}\left(\mathrm{CaCl}_{2}\right)$ the coefficient of determination which was in this case $73.3 \%$ did not essentially increase. In different fields the values of acid ammonium acetate-extractable magnesium calculated on the basis of the mean values of magnesium extracted with $1 \mathrm{M}$ am-

Table 6. Exchangeable magnesium extracted by acid ammonium acetate, $1 \mathrm{M}$ ammonium acetate (pH 7$)$ and $1 \mathrm{M}$ $\mathrm{KCl}$ in the research material.

\begin{tabular}{|c|c|c|c|c|c|c|c|c|c|c|}
\hline \multirow[t]{2}{*}{ Field } & \multirow{2}{*}{$\begin{array}{c}\text { Number } \\
\text { of } \\
\text { samples }\end{array}$} & \multicolumn{3}{|c|}{$\begin{array}{c}\text { Acid } \mathrm{NH}_{4} \mathrm{OAc} \text { extractable } \\
\mathrm{Mg} \mathrm{mg} / 1 \text { soil }\end{array}$} & \multicolumn{3}{|c|}{$\begin{array}{c}1 \mathrm{M} \mathrm{NH}_{4} \mathrm{OAc} \text { extractable } \\
\mathrm{Mg} \mathrm{mg} / \mathrm{kg} \text { soil }\end{array}$} & \multicolumn{3}{|c|}{$\begin{array}{c}1 \mathrm{M} \mathrm{KCl} \text { extractable } \\
\mathrm{Mg} \mathrm{mg} / \mathrm{kg} \text { soil }\end{array}$} \\
\hline & & $\overline{\mathbf{x}}$ & s & $\mathbf{R}$ & $\tilde{\mathbf{x}}$ & s & $\mathbf{R}$ & $\overline{\mathbf{x}}$ & s & $\mathbf{R}$ \\
\hline 49 & 45 & 226 & 274 & $50-1850$ & 204 & 120 & $44-585$ & 171 & 105 & $35-526$ \\
\hline 54 & 99 & 180 & 158 & $60-950$ & 199 & 160 & $69-952$ & 172 & 146 & $49-864$ \\
\hline 84 & 42 & 134 & 58 & $65-335$ & 160 & 62 & $84-373$ & 137 & 57 & $65-352$ \\
\hline 86 & 46 & 352 & 209 & $40-800$ & 364 & 211 & $55-810$ & 337 & 191 & $32-720$ \\
\hline 88 & 34 & 98 & 54 & $25-235$ & 124 & 52 & $48-261$ & 107 & 54 & $24-246$ \\
\hline 89 & 31 & 97 & 28 & $55-180$ & 145 & 36 & $73-224$ & 141 & 80 & $71-528$ \\
\hline 94 & 6 & 138 & 41 & $75-185$ & 205 & 60 & $137-298$ & 190 & 52 & $134-269$ \\
\hline 96 & 66 & 94 & 50 & $40-345$ & 144 & 60 & $70-357$ & 127 & 60 & $60-341$ \\
\hline 97 & 23 & 67 & 50 & $35-245$ & 94 & 50 & $45-277$ & 77 & 52 & $0-256$ \\
\hline 98 & 38 & 145 & 94 & $40-500$ & 172 & 103 & $36-598$ & 165 & 99 & $48-552$ \\
\hline All & 430 & 163 & 161 & $25-1850$ & 187 & 137 & $36-952$ & 167 & 128 & $0-864$ \\
\hline
\end{tabular}

Table 7. Exchangeable potassium extracted by acid ammonium acetate and $1 \mathrm{M}$ ammonium acetate $(\mathrm{pH} 7)$ in the research material.

\begin{tabular}{|c|c|c|c|c|c|c|c|}
\hline \multirow[t]{2}{*}{ Field } & \multirow{2}{*}{$\begin{array}{l}\text { Number } \\
\text { of } \\
\text { samples }\end{array}$} & \multicolumn{3}{|c|}{$\begin{array}{c}\text { Acid } \mathrm{NH}_{4} \mathrm{OAc} \text { extractable } \\
\mathrm{K} \mathrm{mg} / 1 \text { soil }\end{array}$} & \multicolumn{3}{|c|}{$\begin{array}{c}1 \mathrm{M} \mathrm{NH}_{4} \mathrm{OAc} \text { extractable } \\
\mathrm{K} \mathrm{mg} / \mathrm{kg} \text { soil }\end{array}$} \\
\hline & & $\overline{\mathbf{x}}$ & $\mathbf{s}$ & $\mathbf{R}$ & $\overline{\mathbf{x}}$ & $s$ & $\mathbf{R}$ \\
\hline 49 & 45 & 144 & 98 & $20-330$ & 198 & 127 & $53-510$ \\
\hline 54 & 99 & 233 & 142 & $75-1250$ & 306 & 165 & $130-1440$ \\
\hline 84 & 42 & 323 & 108 & $115-580$ & 436 & 157 & $168-838$ \\
\hline 86 & 46 & 310 & 78 & $180-570$ & 356 & 109 & $210-700$ \\
\hline 88 & 34 & 183 & 44 & $118-290$ & 234 & 71 & $129-374$ \\
\hline 89 & 31 & 161 & 114 & $60-695$ & 246 & 158 & $114-970$ \\
\hline 94 & 6 & 169 & 63 & $100-285$ & 296 & 143 & $174-561$ \\
\hline 96 & 66 & 174 & 55 & $85-325$ & 276 & 73 & $155-480$ \\
\hline 97 & 23 & 232 & 87 & $90-450$ & 357 & 139 & $125-765$ \\
\hline 98 & 38 & 265 & 82 & $50-405$ & 356 & 139 & $65-643$ \\
\hline All & 430 & 224 & 115 & $20-1250$ & 305 & 147 & $53-1440$ \\
\hline
\end{tabular}


monium acetate $(\mathrm{pH}$ 7) deviated from the mean values as follows:
(No. of

samples)

$49(45)-20.0$

$54(99)-2.6$

$84(42)+1.8$

$86(46)-3.3$

$88(34)+2.4$
Field Deviation, \%
Field Deviation, \% (No. of samples)

$89(31)+25.2$

$94(6)+31.4$

$97(23)+5.1$

$98(38)+2.3$
$96(66)+28.1$

Magnesium extracted with $1 \mathrm{M} \mathrm{KCl}$ explained $68.6 \%$ of the variation in acid ammonium acetate-extractable magnesium, the regression equation being $\mathrm{Mg}=-10.0+$ $1.0 \mathrm{Mg}(\mathrm{KCl})$. Considering the effect of $\mathrm{pH}\left(\mathrm{CaCl}_{2}\right)$, the coefficient of determination increased to $70.2 \%$.

Exchangeable magnesium was not highly related to the particle-size distribution, organic carbon content nor $\mathrm{pH}\left(\mathrm{CaCl}_{2}\right)$ of soil. Clay and silt content together explained only $28 \%$ of the variation of acid ammonium acetateextractable magnesium. These variables together with $\mathrm{pH}\left(\mathrm{CaCl}_{2}\right)$ explained $50 \%$ of the variation and adding the organic carbon content to the variables increased the coefficient of determination only to $52 \%$.

Clay content and $\mathrm{pH}\left(\mathrm{CaCl}_{2}\right)$ together explained $56 \%$ of the variation in the content of magnesium extracted with $1 \mathrm{M}$ ammonium acetate $(\mathrm{pH} \mathrm{7})$ and $52 \%$ of the variation in the content of magnesium extracted with $1 \mathrm{M}$ $\mathrm{KCl}$. Clay and silt content together with $\mathrm{pH}\left(\mathrm{CaCl}_{2}\right)$ explained $64 \%$ of the variation in acetate-extractable magnesium and $60 \%$ of the $\mathrm{KCl}$-extractable magnesium. Adding the content of organic carbon to the variables increased the coefficient of determination to $66 \%$ (1 M acetate-extractable Mg) and $62 \%$ (1 M KCl-extractable $\mathrm{Mg}$ ).

Exchangeable potassium.. The content of potassium extracted with acid ammonium acetate averaged $224 \mathrm{mg} / 1$ soil, range 20$1250 \mathrm{mg} / \mathrm{l}$ soil (Table 7). The content of potassium extracted with $1 \mathrm{M}$ ammonium acetate $(\mathrm{pH} 7)$ averaged $305 \mathrm{mg} / \mathrm{kg}$ soil, range 53$1440 \mathrm{mg} / \mathrm{kg}$ soil. Potassium extracted with acid ammonium acetate was highly correlated with potassium extracted with $1 \mathrm{M}$ ammonium acetate $\left(\mathrm{r}=0.95^{* * *}\right)$. The regression equation was $\mathrm{K}=-3.07+0.75 \mathrm{~K}$ (Acet.pH 7) and the coefficient of determination $90.3 \%$. Addition of $\mathrm{pH}\left(\mathrm{CaCl}_{2}\right)$ to variables increased the coefficient of determination to $92.3 \%$. In different fields the values calculated from the regression equation deviated from the mean content of potassium extracted with acid ammonium acetate as follows:
Field Deviation, \%

(No. of

samples)

49(45) $\quad+0.7$

$54(99)-2.8$

84(42) +0.3

$86(46) \quad-14.9$

$88(34)-5.8$
Field Deviation, \% (No. of samples)

$89(31)+12.7$

$94(6)+29.5$

$96(66)+17.2$

$97(23)+14.1$

$98(38)-0.4$
The dependence of exchangeable potassium on soil properties was weak. The content of clay and organic carbon together with $\mathrm{pH}\left(\mathrm{CaCl}_{2}\right)$ explained only $19 \%$ of the variation in potassium extracted with $1 \mathrm{M}$ ammonium acetate ( $\mathrm{pH} 7)$. The content of clay, silt and organic carbon together explained $22 \%$ of the variation in potassium extracted with acid ammonium acetate.

Extractable phosphorus. Phosphorus extracted with acid ammonium acetate averaged $23 \mathrm{mg} / \mathrm{l}$ soil and ranged from 4 to $92 \mathrm{mg} / 1$ soil (Table 8). Phosphorus extracted by the Bray 1 method averaged $112 \mathrm{mg} / \mathrm{kg}$ soil, range $2-355 \mathrm{mg} / \mathrm{kg}$ soil. The correlation between phosphorus extracted by these two methods was not very close $\left(r=0.62^{* * *}\right)$. Phosphorus extracted by the Bray 1 method explained only $37.7 \%$ of the variation in phosphorus extracted with acid ammonium acetate. When the effect of $\mathrm{pH}\left(\mathrm{CaCl}_{2}\right)$ was considered, the coefficient of determination increased to $59.5 \%$, the regression equation being $\mathrm{P}=$ $-42.4+9.9 \mathrm{pH}+0.11 \mathrm{P}$ (Bray). Adding the content of clay and organic carbon to the variables increased the coefficient of determination only to $62.1 \%$. 
Table 8. Phosphorus extracted by acid ammonium acetate and the Bray 1 method in the research material.

\begin{tabular}{|c|c|c|c|c|c|c|c|}
\hline \multirow[t]{2}{*}{ Field } & \multirow{2}{*}{$\begin{array}{c}\text { Number } \\
\text { of } \\
\text { samples }\end{array}$} & \multicolumn{3}{|c|}{$\begin{array}{c}\text { Acid } \mathrm{NH}_{4} \mathrm{OAc} \text { extractable } \\
\mathrm{P} \mathrm{mg} / 1 \text { soil }\end{array}$} & \multicolumn{3}{|c|}{$\begin{array}{c}\text { Bray } 1 \\
\mathrm{P} \mathrm{mg} / \mathrm{kg} \text { soil }\end{array}$} \\
\hline & & $\overline{\mathrm{x}}$ & s & $\mathbf{R}$ & $\tilde{\mathbf{x}}$ & s & $\mathbf{R}$ \\
\hline 49 & 45 & 26 & 14 & $4-54$ & 82 & 49 & $5-206$ \\
\hline 54 & 99 & 32 & 10 & $13-65$ & 173 & 66 & $53-355$ \\
\hline 84 & 42 & 15 & 6 & $9-40$ & 94 & 34 & $44-196$ \\
\hline 86 & 46 & 32 & 9 & $18-60$ & 131 & 54 & $64-292$ \\
\hline 88 & 34 & 22 & 8 & $13-39$ & 109 & 36 & $50-176$ \\
\hline 89 & 31 & 17 & 4 & $12-27$ & 114 & 33 & $53-194$ \\
\hline 94 & 6 & 9 & 2 & $8-12$ & 18 & 11 & $2-30$ \\
\hline 96 & 66 & 12 & 11 & $6-92$ & 55 & 28 & $14-151$ \\
\hline 97 & 23 & 18 & 4 & $13-27$ & 128 & 45 & $63-228$ \\
\hline 98 & 38 & 23 & 11 & $9-64$ & 100 & 43 & $32-197$ \\
\hline All & 430 & 23 & 12 & $4-92$ & 112 & 62 & $2-355$ \\
\hline
\end{tabular}

Extractable phosphorus was only weakly related to soil properties. The content of silt and organic carbon together with $\mathrm{pH}\left(\mathrm{CaCl}_{2}\right)$ explained $31.5 \%$ of the variation in acid ammonium acetate-extractable phosphorus. The variable which explained the variation in phosphorus extracted by the Bray 1 method was primarily the clay content. However, it explained only $26.7 \%$ of the variation in phosphorus. When the effects of $\mathrm{pH}\left(\mathrm{CaCl}_{2}\right)$ and the content of silt fraction were also considered, the coefficient of determination increased to $30 \%$.

\section{Discussion}

In the visual classification of soil textural class, clay soils were well distinquished from coarser soils. In the present material of 430 samples only four clay samples were included in coarser soil groups. However, classification of clay soils into groups of silty and sandy clays was not equally successful. According to the estimation, these clay soil groups included a total of 194 samples. About $20 \%$ of them were estimated as silty clays which was not a true classification. If the criterion of silty clay is a content of coarser fractions under $20 \%$, all 194 samples are sandy clays.
In the visual humus content classification, the content of organic matter was frequently underestimated. Only $36 \%$ of 327 samples classified in the humus content class "medium" truly belonged to this class. On the basis of organic carbon content the majority of these samples should be classified as $»$ rich». The humus content class wrich" included 88 sainples of which $33 \%$ truly belonged to this class, while nearly all other samples should be classified as "very rich». A factor rendering the humus content classification more difficult is the relatively high content of organic matter in the present material. If soils with greater variation in the content of organic matter are not included for comparison, the possibility of faulty estimations increases.

The values of $\mathrm{pH}\left(\mathrm{H}_{2} \mathrm{O}\right)$ and $\mathrm{pH}\left(\mathrm{CaCl}_{2}\right)$ were highly correlated, which is in agreement with previous results of RYTI (1965), MÃNTYLAHTI and Yläranta (1980) and SillanPäĀ (1982). In the material of RYTI (1965) the mean difference between $\mathrm{pH}\left(\mathrm{H}_{2} \mathrm{O}\right)$ and $\mathrm{pH}\left(\mathrm{CaCl}_{2}\right)$ was $0.5 \mathrm{pH}$ units. Also in the present study the $\mathrm{pH}\left(\mathrm{H}_{2} \mathrm{O}\right)$ values were about $0.5 \mathrm{pH}$ units higher than the $\mathrm{pH}\left(\mathrm{CaCl}_{2}\right)$ values. The regression equation between $\mathrm{pH}\left(\mathrm{H}_{2} \mathrm{O}\right)$ and $\mathrm{pH}\left(\mathrm{CaCl}_{2}\right)$ obtained in this study agreed fairly well with the regression 
equation obtained by RYTI (1965) for sand and finesand soils $\left(\mathrm{pH}\left(\mathrm{H}_{2} \mathrm{O}\right)=0.81+0.94\right.$ $\left.\mathrm{pH}\left(\mathrm{CaCl}_{2}\right), \mathrm{n}=109, \mathrm{r}=0.97^{* * *}\right)$. The mean $\mathrm{pH}\left(\mathrm{H}_{2} \mathrm{O}\right)$ values of different fields were well predicted with the regression equation calculated from the whole material. The difference between measured and calculated value was no more than $0.1 \mathrm{pH}$ units excluding field No. 86 where the content of organic carbon was lower than in most other fields. The values of $\mathrm{pH}\left(\mathrm{H}_{2} \mathrm{O}\right)$ and $\mathrm{pH}\left(\mathrm{CaCl}_{2}\right)$ were not closely related to the soil particle-size distribution or organic carbon content. This could also be expected on the basis of a previous study with nearly the same material (JOKINEN 1984).

In cultivated soils, the majority of the cation exchange capacity is saturated with exchangeable calcium. According to KAILA (1972), the degree of saturation with calcium varies from $60 \%$ to $80 \%$. Under these circumstances it was not surprising that $\mathrm{pH}\left(\mathrm{CaCl}_{2}\right)$, clay content and organic carbon content, factors on which the cation exchange capacity is highly dependent (HeINONEN 1960, MARTTILA 1965, KaILA 1971), explained more than $70 \%$ of the exchangeable calcium extracted by three methods. More than $90 \%$ of the variation in acid ammonium acetate extractable-calcium was explained by $\mathrm{pH}\left(\mathrm{CaCl}_{2}\right)$ together with calcium extracted with $1 \mathrm{M}$ ammonium acetate $(\mathrm{pH} \mathrm{7})$ or $1 \mathrm{M} \mathrm{KCl}$. The mean values of acid ammonium acetate-extractable calcium in different fields were predicted rather well on the basis of $\mathrm{pH}$ and calcium extracted by the comparative methods. However, the contents were not similar. The acid acetate extracted much less calcium from the soil than did the neutral acetate or $\mathrm{KCl}$. The different extraction method explains part of the difference. According to the regression analysis, an increment of one unit of the latter values corresponded to 0.6 unit of the former.

The magnesium status fluctuated more than did calcium status in the experimental area. Exchangeable magnesium, a minor component in saturation of cation exchange capaci- ty, was not very highly related to soil characteristics which explained $52-66 \%$ of the variation in exchangeable magnesium. According to KaILA (1972), $10-30 \%$ of the cation exchange capacity of cultivated soils is saturated with magnesium. The mean values of acid ammonium acetate-extractable magnesium in different fields were not predicted as well as calcium values on the basis of comparative methods. At its highest the deviation was about $30 \%$. On the average, the contents determined by different methods did not deviate very much from each other. According to the regression analysis, the mean differences between samples were equal irrespective of the method used.

As previously observed (JOKINEN 1984), exchangeable potassium was poorly related to soil $\mathrm{pH}$, particle-size distribution and organic carbon content. Potassium extracted with acid ammonium acetate was highly related to potassium extracted with $1 \mathrm{M}$ ammonium acetate. With the exception of one field $(94,6$ samples), the mean values of acid ammonium acetate-extractable potassium were rather well predicted on the basis of the comparative method. The acid acetate extracted on an average $75 \%$ of the potassium extracted by the neutral acetate.

Phosphorus extracted with acid ammonium acetate, representing relatively well available phosphorus in soil, was not highly related to phosphorus extracted by the Bray 1 method, which indicates the capacity factor of the soil phosphorus status (KaIla 1965). More phosphorus was extracted by the Bray 1 method than with acid ammonium acetate. In the study of AURA (1978) with 30 soils and in the study of SipPOLA and JAAKKOLA (1980) with 20 soils, a 5-fold amount of phosphorus per liter of soil on the average was extracted by the Bray 1 method as compared with phosphorus extracted with acid ammonium acetate. The relationship between the methods in this study was also of the same magnitude. An accurate comparison was not possible because the former content was expressed on a 
volume basis, the latter on a weight basis. In the study of AURA (1978), the phosphorus uptake of oats in four growings in pots was better explained by phosphorus extracted with acid ammonium acetate $(77 \%)$ than by phosphorus extracted by the Bray 1 method
(48 \%). Phosphorus extracted by any method was not very well explained by $\mathrm{pH}$, organic carbon or clay and silt content, which is in agreement with the study of Sippola and JANSSON (1979) on soil phosphorus extractable with acid ammonium acetate.

\section{References}

AurA, E. 1978. Determination of available soil phosphorus by chemical methods. J. Scient. Agric. Soc. Finl. 50: 305-316.

BraY, R. H. \& KuRTZ, L. T. 1945. Determination of total, organic and available forms of phosphorus in soils. Soil Sci. 59: 39-45.

Elonen, P. 1971. Particle-size analysis of soil. Acta Agr. Fenn. 122: 1-122.

Graham, E. R. 1948. Determination of soil organic matter by means of a photoelectric colorimeter. Soil Sci. 65: $181-183$.

HeInonen, R. 1960. Über die Umtauschkapazităt des Bodens und verschiedenen Bodenbestandteile in Finnland. Z. Pflanzenern. Düng. Bodenk. 88: 49-59.

JOKINEN, R. 1983. Variability of topsoil properties at the southern coast of Finland and the number of soil samples needed for the estimation of soil properties. J. Scient. Agric. Soc. Finl. 55: 109-117.

- 1984. Comparison of and correlation between the characteristics of agricultural topsoil and subsoil at the southern coast of Finland. J. Agric. Sci. Finl. 56: 245254.

KAILA, A. 1955. Studies on the colorimetric determination of phosphorus in soil extracts. Acta Agr. Fenn. 83: $25-47$.

- 1965. Some phosphorus test values and fractions of inorganic phosphorus in soils. J. Scient. Agric. Soc.
Finl. 37: 175-185.

- 1971. Effective cation-exchange capacity in Finnish mineral soils. J. Scient. Agric. Soc. Finl. 43: 178-186.

- 1972. Basic exchangeable cations in Finnish mineral soils. J. Scient. Agric. Soc. Finl. 44: 164-170.

MartTILA, U. 1965. Exchangeable cations in Finnish soils. J. Scient. Agric. Soc. Finl. 37: 148-161.

Mãntylahtı, V. \& Yläranta, T. 1980. The estimation of soil lime requirement in soil testing. Ann. Agric. Fenn. 19: 92-99.

RYTI, R. 1965. On the determination of soil pH. J. Scient. Agric. Soc. Finl. 37: 51-60.

SillanPÃÃ, M. 1982. Micronutrients and the nutrient status of soils: a global study. 444 p. Rome.

Sippola, J. \& JAAKKolA, A. 1980. Maasta eri menetelmillă măăritetyt typpi, fosfori ja kalium lannoitustarpeen osoittajina astia- ja kenttăkokeissa. Maatalouden tutkimuskeskus, Maanviljelyskemian ja -fysiikan laitos, Tiedote N:o 13: 24-41.

— \& Jansson, H. 1979. Soil phosphorus test values obtained by acid ammonium acetate, water and resin extraction as predictors of phosphorus content in timothy (Phleum pratense L.). Ann. Agric. Fenn. 18: 225-230. VUORINEn, J. \& MÃKITIE, O. 1955. The method of soil testing in use in Finland. Agrogeol. Publ. 63: 1-44.

Ms received June 9, 1985 


\section{SELOSTUS}

\section{Maan viljavuuden määrittämiseen käytettyjen analyysimenetelmien vertailu}

\author{
Raina Niskanen ja Antti Jaakkola \\ Helsingin yliopisto, Maanviljelyskemian laitos, \\ 00710 Helsinki 71
}

Tutkimusaineisto koostui 430 Viikin opetus- ja koetilan peltojen muokkauskerroksesta otetusta maanäytteestä. Nảytteistå määritettiin lajitekoostumus, orgaaninen hiili, $\mathrm{pH}\left(\mathrm{CaCl}_{2}\right)$, vaihtuva $\mathrm{Ca}$ ja $\mathrm{Mg}$ uutettuna $1 \mathrm{M}$ ammoniumasetaatilla $(\mathrm{pH} \mathrm{7)}$ sekä $1 \mathrm{M} \mathrm{KCl:lla,} \mathrm{vaihtuva} \mathrm{K}$ uutettuna $1 \mathrm{M}$ ammoniumasetaatilla $(\mathrm{pH} 7)$ ja $\mathrm{P}$ uutettuna Bray 1 -menetelmăllă. Näită maan ominaisuuksia verrattiin Viljavuuspalvelu Oy:ssä tehdyn viljavuusanalyysin tuloksiin.

Aistinvaraisella măărityksellă pystyttiin maalaji tunnistamaan tyydyttåvăsti, mutta multavuus arvioitiin usein văhäisemmäksi kuin orgaanisen hiilen pitoisuuden perusteella saatiin. Vesilietoksesta mitatun $\mathrm{pH}: \mathrm{n}$ vaihtelusta $0.01 \mathrm{M} \mathrm{CaCl}_{2}$-lietoksesta mitattu pH selitti $95 \%$. Vesilietoksesta mitattu $\mathrm{pH}$ oli suunnilleen $0.5 \mathrm{pH}$-yksikköă korkeampi kuin $\mathrm{pH}\left(\mathrm{CaCl}_{2}\right)$. Happamella ammoniumasetaatilla uutetun kalsiumin vaihtelusta vaihtuva kalsium yhdessă $\mathrm{pH}\left(\mathrm{CaCl}_{2}\right)$ :n kanssa selitti noin $90 \%$. Happamella ammoniumasetaatilla uutetun magnesiumin vaihtelusta vaihtuva magnesium selitti noin $70 \%$. Happamella ammoniumasetaatilla uuttuvan kaliumin vaihtelusta vaihtuva kalium selitti $90 \%$. Happamella ammoniumasetaatilla uutetun fosforin vaihtelusta Bray 1 -menetelmăllă uutettu fosfori yhdessä $\mathrm{pH}\left(\mathrm{CaCl}_{2}\right): \mathrm{n}$ kanssa selitti $60 \%$. Eri menetelmillă uutetun kalsiumin vaihtelusta $\mathrm{pH}\left(\mathrm{CaCl}_{2}\right)$ yhdessä saveksen ja orgaanisen hiilen pitoisuuden kanssa selitti $72-83 \%$. Uuttuvan magnesiumin, kaliumin ja fosforin riippuvuus maan $\mathrm{pH}: \mathrm{sta}$, lajitekoostumuksesta ja orgaanisen hiilen pitoisuudesta oli varsin heikko. 